\title{
Chapter 1 \\ Supershear Earthquake Ruptures - Theory, Methods, Laboratory Experiments and Fault Superhighways: An Update
}

\author{
Shamita Das
}

\begin{abstract}
The occurrence of earthquakes propagating at speeds not only exceeding the shear wave speed of the medium $(\sim 3 \mathrm{~km} / \mathrm{s}$ in the Earth's crust), but even reaching compressional wave speeds of nearly $6 \mathrm{~km} / \mathrm{s}$ is now well established. In this paper, the history of development of ideas since the early 1970s is given first. The topic is then discussed from the point of view of theoretical modelling. A brief description of a method for analysing seismic waveform records to obtain earthquake rupture speed information is given. Examples of earthquakes known to have propagated at supershear speed are listed. Laboratory experiments in which such speeds have been measured, both in rocks as well as on man-made materials, are discussed. Finally, faults worldwide which have the potential to propagate for long distances (>about $100 \mathrm{~km}$ ) at supershear speeds are identified ("fault superhighways").
\end{abstract}

\subsection{Introduction}

Seismologists now know that one of the important parameters controlling earthquake damage is the fault rupture speed, and changes in this rupture speed (Madariaga 1977, 1983). The changes in rupture speed generate high-frequency damaging waves Thus, the knowledge of how this rupture speed changes during earthquakes and its maximum possible value are essential for reliable earthquake hazard assessment. But how high this rupture speed can be has been understood only relatively recently. In the 1950-1960s, it was believed that earthquake ruptures could only reach the Rayleigh wave speed. This was based partly on very idealized models of fracture mechanics, originating from results on tensile crack propagation velocities which cannot exceed the Rayleigh wave speed and which were simply

\footnotetext{
S. Das $(\bowtie)$

Department of Earth Sciences, University of Oxford, Oxford OX1 3AN, UK

e-mail: das@earth.ox.ac.uk
} 
transferred to shear cracks. But more importantly, seismologists estimated the average rupture speed for several earthquakes by studying the directivity effects and spectra of seismic waves. The first was for the 1952 Ms 7.6 Kern County, California earthquake. Benioff (1955) concluded that "the progression speed is in the neighborhood of speed of Rayleigh waves" using body wave studies. Similar conclusions were reached for several great earthquakes, including the 1960 great Chile earthquake (Press et al. 1961), the 1957 Mongolian earthquake (Ben-Menahem and Toksöz 1962), the 1958 Alaska earthquake (Brune 1961, 1962; Ben-Menahem and Toksöz 1963a) and the 1952 Kamchatka earthquake (Ben-Menahem and Toksöz 1963b) by studying directivity effects and/or spectra of very long wave length surface waves.

In the early 1970s, Wu et al. (1972) conducted laboratory experiments on plastic polymer, under very low normal stresses, and found supershear rupture speeds. This was considered unrealistic for real earthquakes, both the material and the low normal stress, and the results were ignored. Soon after, Burridge (1973) demonstrated that faults with friction but without cohesion across the fault faces could exceed the shear wave speed and even reach the compressional wave speed of the medium. But since such faults are unrealistic for actual earthquakes, the results were again not taken seriously. In the mid- to late 1970s the idea that for in-plane shear faults with cohesion, terminal speeds exceeding not only the Rayleigh wave speed but even being as high as the compressional-wave speed was possible finally started being accepted, based on the work of Hamano (1974), Andrews (1976), Das (1976), and Das and Aki (1977). Once the theoretical result was established, scientists interpreting observations became more inclined to believe results showing supershear fault rupture speeds, and at the same time the data quality and the increase in the number of broadband seismometers worldwide, required to obtain detailed information on fault rupture started becoming available. Thus, the theory spurred the search for supershear earthquake ruptures.

The first earthquake for which supershear wave rupture speed was inferred was the 1979 Imperial Valley, California earthquake which had a moment-magnitude (Mw) of 6.5, studied by Archuleta (1984), and by Spudich and Cranswick (1984) using strong motion accelerograms. But since the distance for which the earthquake propagated at the high speed was not long, the idea was still not accepted universally. And then for nearly 25 years there were no further developments, perhaps because earthquakes which attain supershear speeds are rare, and none are known to have occurred. This provided ammunition to those who resisted the idea of supersonic earthquake rupture speeds being possible.

Then, in the late 1990 to early 2000s, there were two major developments. Firstly, a group at Caltech, led by Rosakis, measured earthquake speeds in the laboratory, not only exceeding the shear wave speed (Rosakis et al. 1999; Xia et al. 2004) but even reaching the compressional wave speed (Xia et al. 2005). Secondly, several earthquakes with supershear wave rupture speeds actually occurred, with one even reaching the compressional wave speed. The first of these was the strike-slip earthquake of 1999 with Mw 7.6 in Izmit, Turkey (Bouchon et al. 2000, 2001), with a total rupture length of $\sim 150 \mathrm{~km}$, and with the 
length of the section rupturing at supershear speeds being about $45 \mathrm{~km}$. This study was based on two components of near-fault accelerograms recorded at one station (SKR). Then two larger supershear earthquakes occurred, namely, the $2001 \mathrm{Mw} 7.8$ Kunlun, Tibet earthquake (Bouchon and Vallée 2003; Antolik et al. 2004; Robinson et al. 2006b; Vallée et al. 2008; Walker and Shearer 2009), and the $2002 \mathrm{Mw} 7.9$ Denali, Alaska earthquake (Dunham and Archuleta 2004; Ellsworth et al. 2004; Frankel 2004; Ozacar and Beck 2004; Walker and Shearer 2009). Both were very long, narrow intra-plate strike-slip earthquakes, with significantly long sections of the faults propagating at supershear speeds. At last, clear evidence of supershear rupture speeds was available. Moreover, by analysing body wave seismograms very carefully, Robinson et al. (2006b) showed that not only did the rupture speed exceed the shear wave speed of the medium; it reached the compressional wave speed, which is about $70 \%$ higher than the shear wave speed in crustal rocks.

Once convincing examples of supershear rupture speeds started to be found, theoretical calculations were carried out (Bernard and Baumont 2005; Dunham and Bhat 2008) and these suggested that the resulting ground shaking can be much higher for such rapid ruptures, due to the generation of Mach wave fronts. Such wave fronts, analogous to the "sonic boom" from supersonic jets, are characteristics and their amplitudes decrease much more slowly with distance than usual spherical waves do. Of course, much work still remains to be done in this area. Figure 1.1 shows a schematic illustrating that formulae from acoustics cannot be directly transferred to seismology. The reason is that many regions of the fault area are simultaneously moving at these high speeds, each point generating a Mach cone,

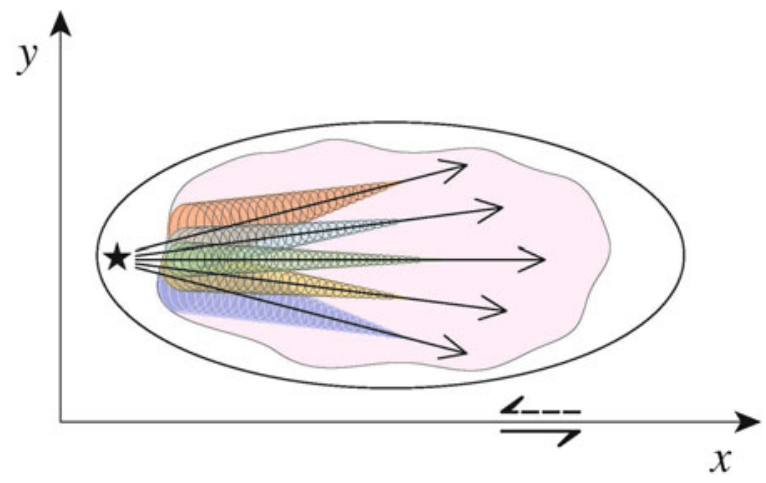

Fig. 1.1 Schematic representation of the leading edges of the multiple S-wave Mach cones generated by a planar fault spreading out in many directions, along the black arrows, from the hypocenter (star). The pink shaded region is the region of supershear rupture. The thick black arrows show the direction of the applied tectonic stress across the $x-y$ plane. Supershear speeds cannot be reached in the $y$ - direction (that is, by the Mode III or the anti-plane shear mode). The higher the rupture speed, the narrower each cone would be. Dunham and Bhat (2008) showed that additional Rayleigh wave Mach fronts would be generated along the Earth's surface during supershear earthquake ruptures 
and resulting in a the Mach surface. Moreover, different parts of the fault could move at different supershear speeds, again introducing complexity into the shape and amplitudes of the Mach surface. Finally, accounting for the heterogeneity of the medium surrounding the fault through which these Mach fronts propagate would further modify the Mach surface. There could be special situations where the individual Mach fronts comprising the Mach surface could interfere to even lower, rather than raise, the resulting ground shaking. Such studies would be of great interest to the earthquake engineering community.

\subsection{Theory}

Since damaging high-frequency waves are generated when faults change speed (Madariaga 1977, 1983), the details of how faults start from rest and move at increasing speeds is very important. Though in-plane shear faults (primarily strikeslip earthquakes) can not only exceed the shear wave speed of the medium, but can even reach the compressional wave speed, steady-state (constant speed) calculations on singular cracks (with infinite stress at the fault edges) had shown that speeds between the Rayleigh and shear wave speeds were not possible, due to the fact that in such a case there is negative energy flux into the fault edge from the surrounding medium, that is, such a fault would not absorb elastic strain-energy but generate it (Broberg 1989, 1994, 1999). Theoretical studies by Andrews (1976) and Burridge et al. (1979) using the non-singular slip-weakening model (Fig. 1.2), introduced by Ida (1972) suggested that even for such 2-D in-plane faults which start from rest and accelerate to some terminal velocity, such a forbidden zone does exist.

Fig. 1.2 The linear "slipweakening model", relating the fault slip to the stress at the edge of the fault. The region between 0 to $d o$ is called the "break-down" zone, where the earthquake stress release occurs. CruzAtienza and Olsen (2010) estimated $d o$ to be $\sim 2 \mathrm{~m}$ for the 1999 Izmit, Turkey and 2002 Denali, Alaska earthquakes

\section{SLIP-WEAKENING MODEL}

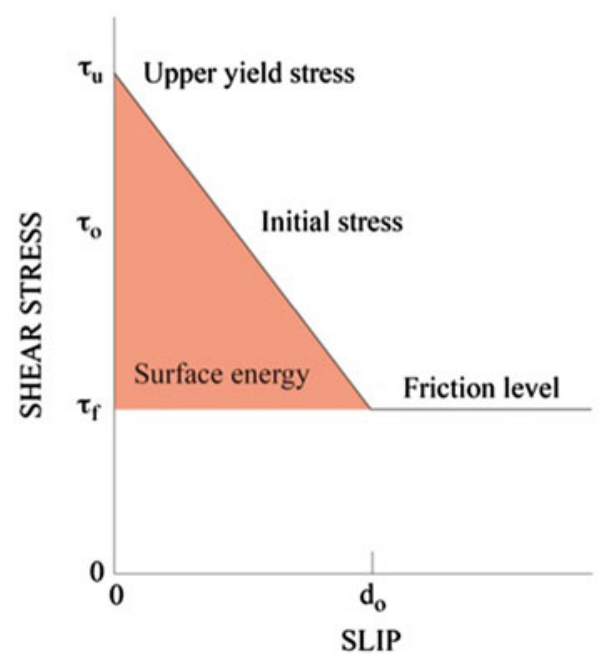


Recent work of Bizzari and Das (2012) showed that for the 3-D mixed in-plane and anti-plane shear mode fault, propagating under this slip-weakening law, the rupture front actually does pass smoothly through this forbidden zone, but very fast. The width of the cohesive zone initially decreases, then increases as the rupture exceeds the shear wave speed and finally again decreases as the rupture accelerates to a speed of $\sim 90 \%$ of the compressional wave speed. The penetration of the 'forbidden zone' has very recently also been confirmed for the 2-D in-plane shear fault for the same linear slip-weakening model by Liu et al. (2014). To reiterate, this is important as this smooth transition from sub- to super- shear wave speeds would reduce damage.

\subsection{Seismic Data Analysis}

The inverse problem of earthquake source mechanics consists of analysing seismograms to obtain the details of the earthquake rupture process. This problem is known to be unstable (Kostrov 1975; Olson and Apsel 1982; Kostrov and Das 1988; Das and Kostrov 1990) and requires additional constraints to stabilize it. In order to demonstrate the basic ideas involved, we follow the formulation of Das and Kostrov (1990, 1994) here.

By modifying the representation theorem (e.g., equation (3.2) of Aki and Richards (1980, 2002); equation (3.2.18) of Kostrov and Das (1988)), the displacement at a seismic station can be written as the convolution of the components of the slip rate on the fault with a step-function response of the medium. Note that the usual formulation convolves the slip with the delta function response of the medium, but since moving the time derivative from one term of the convolution to the other does not change the value of the integral, Das and Kostrov's formulation uses the slip rate on the fault convolved with a singular term but with a weaker integrable singularity, making the problem mathematically more tractable and more stable. The convolution extends over the fault area and the time over which the fault slips. Full details can be found in Das and Kostrov (1990, 1994). The resulting integral equation is of the first kind and known to be unstable. Thus, these authors stabilized the equations by adding physically-based additional constraints, the most important of this being that the slip-rate on the fault is non-negative, called the "nobackslip constraint". Numerical modelling of ruptures show that this is very likely for large earthquakes. To solve the integral equation numerically, it must be discretized. For this, the fault area is divided into a number of rectangular cells and the slip-rate is approximated within each cell by linear functions in time and along strike and by a constant along dip. The time at the source is discretized by choosing a fixed time step, and assuming that the slip rate during the time step varies linearly with time. The Heaviside kernel is then integrated over each cell analytically, and the integrals over the fault area and over time are replaced by sums. The optimal size of the spatial cells and the time steps should be determined 
by some synthetic tests, as discussed, for example by Das and Suhadolc (1996), Das et al. (1996), and Sarao et al. (1998) for inversions using strong ground motion data and by Henry et al. (2000, 2002) for teleseismic data inversions. The fault area and the total source duration are not assigned a priori but determined as part of the inversion process. An initial fault area is assigned based on the aftershock area and then refined. An initial value of the finite source duration is estimated, based on the fault size and a range of average rupture speeds, and it cannot be longer than the longest record used. The integral equation then takes the form of a system of linear equations $\mathrm{A} \mathbf{x} \approx \mathbf{b}$, where $\mathrm{A}$ is the kernel matrix obtained by integrating it over each cell, each column of A corresponding to different cells and time instants of the source duration, ordered in the same way as the vector of observed seismograms $\mathbf{b}$, and $\mathbf{x}$ is vector of unknown slip rates on the different cells on the fault at different source time-steps. The no back-slip constraint then becomes $\mathbf{x} \geq 0$. In order to reduce the number of unknowns, a very weak causality condition could be introduced, for example, $x$ 's beyond the first compressional wave from the hypocenter could be set to 0 . If desired, the seismic moment could be required to be equal to that obtained say, from the centroid-moment tensor (CMT) solution. With the highquality of broadband data now available, this constraint is not necessary and it is found that when stations are well distributed in azimuth around the earthquake, the seismic moment obtained by the solution is close to the CMT moment. In addition, Das and Kostrov $(1990,1994)$ permitted the entire fault behind the rupture front to slip, if the data required it, unlike studies where slipping is confined only to the vicinity of the rupture front. If there is slippage well behind the main rupture front in some earthquake, then this method would find it whereas others would not. Such a case was found by Robinson et al. (2006a) for the $2001 \mathrm{Mw} 8.4$ Peru earthquake.

Thus, the inverse problem is the solution of the linear system of equations under one or more constraints, in which the number of equations $m$ is equal to the total number of samples taken from all the records involved and the number of unknowns $n$ is equal to the number of spatial cells times on the fault times the number of time steps at the source. Taking $m>n$, the linear system is over determined and a solution $\mathbf{x}$ which provides a best fit to the observations is obtained. It is well known that the matrix $\mathrm{A}$ is often ill-conditioned which implies that the linear system admits more than one solution, equally well fitting the observations. The introduction of the constraints reduces the set of permissible (feasible) solutions. Even when an unique solution does exist, there may be many other solutions that almost satisfy the equations. Since the data used in geophysical applications often contain experimental noise and the models used are themselves approximations to reality, solutions almost satisfying the data are also of great interest.

Finally, for the system of equations together with the constraints to comprise a complete mathematical problem, the exact form of what the "best fit" to observations means has to be stated. For this problem, we have to minimize the vector of residuals, $\mathbf{r}=\mathbf{b}-\mathrm{A} \mathbf{x}$, and some norm of the vector $\mathbf{r}$ must be adopted. One may choose to minimize minimize the $\ell_{1}$, the $\ell_{2}$ or the $\ell_{\infty}$ norm (see Tarantola 1987 for a discussion of different norms), all three being equivalent in the sense that they tend 
to zero simultaneously. Das and Kostrov $(1990,1994)$ used the linear programming method to solve the linear system and minimized the $\ell_{1}$ norm subject to the positivity constraint, using programs modified from Press et al. (1986). In various studies, they have evaluated the other two norms of the solution to investigate how they behave, and find that when the data is fitted well, the other two norms are also small. A method with many similarities to that of Das and Kostrov (1990, 1994) was developed by Hartzell and Heaton (1983). Hartzell et al. (1991) also carried out a comprehensive study comparing the results of using different norms in the inversion. Parker (1994) has discussed the positivity constraint in detail.

In order to confirm that the solution obtained is reliable Das and Kostrov (1994), introduced additional levels of optimization. For example, if a region with high or low slip was found, fitting the data by lowering or raising the slip in that region was attempted to see if the data was still well fitted. If it did not, then the features were considered robust. If high rupture speed was found in some portion of the fault, its robustness was treated similarly. All features interpreted geophysically can be tested in this way. Some examples can be found in Das and Kostrov (1994), Henry et al. (2000), Henry and Das (2002), Robinson et al. (2006a, b).

\subsection{A Case Study of a Supershear Earthquake}

\subsubsection{The 2001 Mw 7.8 Kunlun, Tibet Earthquake}

This $>400 \mathrm{~km}$ long earthquake was, at the time of its occurrence, the longest known strike-slip earthquake, on land or underwater, since the 1906 California earthquake. The earthquake occurred on a left-lateral fault, propagating unilaterally from west to east, on one of the great strike-slip faults of Tibet, along which some of the northward motion of the Indian plate under Tibet is accommodated by lateral extrusion of the Tibetan crust. It produced surface ruptures, reported from field observations, with displacements as high as 7-8 $\mathrm{m}$ (Xu et al. 2002), [initially even larger values were estimated by Lin et al. (2002) but these were later revised down], this large value being supported by interferometric synthetic aperture radar (InSAR) measurements (Lasserre et al. 2005), as well as the seismic body wave studies referred to below. Bouchon and Vallée (2003) used mainly Love waves from regional seismograms to show that the average rupture speed was $\sim 3.9 \mathrm{~km} / \mathrm{s}$, exceeding the shear wave speed of the crustal rocks, and P-wave body wave studies confirmed this (Antolik et al. 2004; Ozacar and Beck 2004). More detailed analysis of SH body wave seismograms, using the inversion method of Kostrov and Das (1990, 1994), showed that the rupture speed on the Kunlun fault during this earthquake was highly variable and the rupture process consisted of three stages (Robinson et al. 2006b). First, the rupture accelerated from rest to an average speed of $3.3 \mathrm{~km} / \mathrm{s}$ over a distance of $120 \mathrm{~km}$. The rupture then propagated for another $150 \mathrm{~km}$ at an apparent rupture speed exceeding the $\mathrm{P}$ wave speed, the 


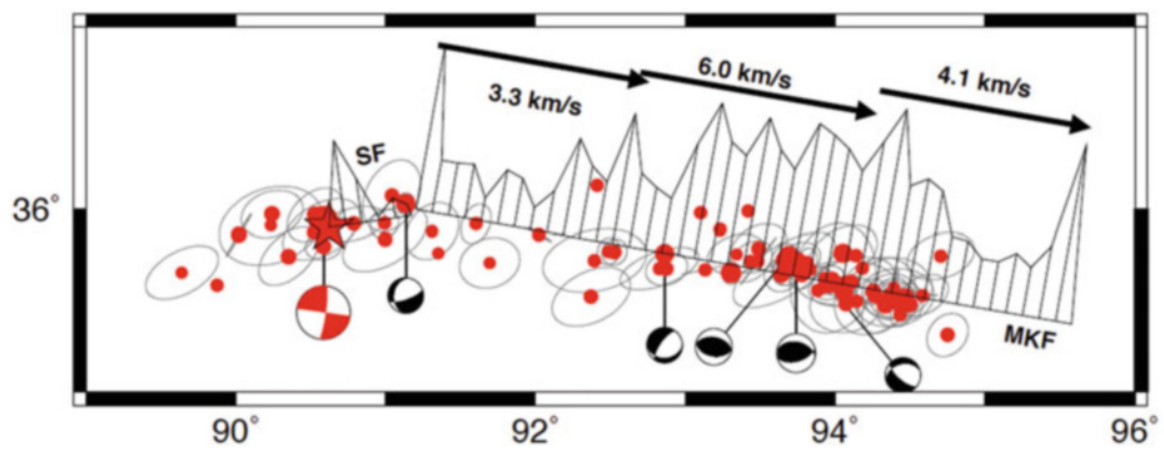

Fig. 1.3 Schematic showing the final slip distribution for the 2001 Kunlun, Tibet earthquake, with the average rupture speeds in 3 segments marked. Relocated aftershocks for the 6 month period following the earthquake (Robinson et al. 2006a, b) are shown as red dots, with the symbol size scaling with earthquake magnitude. The maximum slip is $\sim 6.95 \mathrm{~m}$. The centroid-moment tensor solution for the main shock (star denotes the epicenter, its cmt is in red) and those available for the larger aftershocks (cmts in black) are shown. The longitude (E) and latitude (N) are marked. The impressive lack of aftershocks, both in number and in size, for such a large earthquake was shown by Robinson et al. (2006b)

longest known segment propagating at such a high speed for any earthquake fault (Fig. 1.3). Finally, the fault bifurcated and bent, the rupture front slowed down, and came to a stop at another sharper bend, as shown in Robinson et al. (2006b). The region of the highest rupture velocity coincided with the region of highest fault slip, highest fault slip rate, highest stress drop (stress drop is what drives the earthquake rupture), the longest fault slipping duration and had the greatest concentration of aftershocks. The location of the region of the large displacement has been independently confirmed from satellite measurements (Lasserre et al. 2005). The fault width (in the depth direction) for this earthquake is variable, being no more than $10 \mathrm{~km}$ in most places and about $20 \mathrm{~km}$ in the region of highest slip.

Field observations, made several months later, showed a $\sim 25 \mathrm{~km}$ wide region to the south of the fault in the region of supershear rupture speed, with many off-fault open (tensile) cracks. These open cracks are confined only to the off-fault section of high speed portion of the fault, and were not seen off-fault of the lower rupture speed portions of the fault, though those regions were also visited by the scientists (Bhat et al. 2007). Theoretical results show that as the rupture moves from sub- to super- shear speeds, large normal stresses develop in the off-fault regions close to the fault, as the Mach front passes through. Das (2007) has suggested that observations of such off-fault open cracks could be used as an independent diagnostic tool for identifying the occurrence of supershear rupture and it would be useful to search for and document them in the field for large strike-slip earthquakes.

The special faulting characteristics (Bouchon et al. 2010) and the special pattern of aftershocks for this and other supershear earthquakes (Bouchon and Karabulut 2008) has been recently been noted. 


\subsection{Conditions Necessary for Supershear Rupture}

A striking observation for the 2001 Kunlun earthquake is that that the portion of the fault where rupture propagated at supershear speeds is very long and very straight. Bouchon et al. (2001) showed that for the 1999 Izmit, Turkey earthquake fault the supershear eastern segment of the fault was very straight and very simple, with no changes in fault strike, say, jogs, bends, step-overs, branching etc. Examination of the 2002 Denali, Alaska earthquake fault shows the portion of the fault identified by Walker and Shearer (2009) as having supershear rupture speeds is also long and straight. The Kunlun earthquake showed that a change in fault strike direction slows the fault down, and a large variation in strike stops the earthquake (Robinson et al. 2006b). Based on these, we can say that necessary (though not sufficient) conditions for supershear rupture to continue for significant distances are: (i) The strike-slip fault must be very straight (ii) The longer the straight section, the more likely is supershear speed, provided: (a) fault friction is low (b) no other impediments or barriers exist on the fault. Of course, very locally short sections could reach supershear speeds, but the resulting Mach fronts would be small and local, and thus less damaging. It is the sustained supershear wave speed over long distances that would create large Mach fronts.

\subsection{Laboratory Experiments}

Important support, and an essential tool in the understanding of supershear rupture speeds in earthquakes, comes from laboratory experiments on fracture. As mentioned in the introduction, the first time supershear rupture speeds were ever mentioned with respect to earthquakes was the experiment of Wu et al. (1972). The pioneering work led by Rosakis at Caltech, starting in the late 1990s, finally convinced scientists that such earthquake rupture speeds were possible. Though these experiments were carried out on man-made material (Homalite), and the rupture and wave fronts were photographed, they revolutionised our way of thinking. More recently, Passelègue et al. (2013) at the École Normale Supérieure in Paris obtained supershear rupture speeds in laboratory experiments on rock samples (Westerly granite). The rupture front position was obtained by analysis of acoustic high-frequency recordings on a multistation array. This is clearly very close to the situation in seismology, where the rupture details are obtained by seismogram (time-series) analysis, as discussed earlier. However, in the real Earth, the earthquake ruptures propagate through material at higher temperatures and pressures than those in these experiments. Future plans by the Paris group includes upgrading their equipment to first studying the samples at higher pressures, and then moving on to higher temperatures as well, a more technologically challenging problem. 


\subsection{Potential Supershear Earthquake Hazards}

Earthquakes start from rest and need to propagate for some distance to reach their maximum speed (Kostrov 1966). Once the maximum speed is reached, the earthquake could continue at this speed, provided the fault is straight, and no other barriers exist on it, as mentioned above. Faults with many large changes in strike, or large step-overs, would thus be less likely to reach very high rupture speeds as this would cause rupture on such faults to repeatedly slow down, before speeding up again, if the next segment is long enough. The distance necessary for ruptures to propagate in order to attain supershear speeds is called the transition distance and is currently still a topic of vigorous research and depends on many physical parameters of the fault, such as the fault strength to stress-drop ratio, the critical fault length required to reach supershear speeds, etc. (Andrews 1976; Dunham 2007; Bizzari and Das 2012; Liu et al. 2014).

Motivated by the observation that the rare earthquakes which propagated for significant distances at supershear speeds occurred on very long straight segments of faults, we examined every known major active strike-slip fault system on land worldwide and identified those with long $(>100 \mathrm{~km})$ straight portions capable not only of sustained supershear rupture speeds but having the potential to reach compressional wave speeds over significant distances, and call them "fault superhighways". Detailed criteria for each fault chosen to be considered a superhighway are discussed in Robinson et al. (2010), including when a fault segment is considered to be straight. Every fault selected, except one portion of the Red River fault and the Dead Sea Fault has had earthquakes of magnitude $>7$ on it in the last 150 years. These superhighways, listed in Table 1.3, include portions of the $1,000 \mathrm{~km}$ long Red River fault in China and Vietnam passing through Hanoi, the $1,050 \mathrm{~km}$ long San Andreas fault in California passing close to Los Angeles, Santa Barbara and San Francisco, the 1,100 km long Chaman fault system in Pakistan north of Karachi, the $700 \mathrm{~km}$ long Sagaing fault connecting the first and second cities of Burma (Rangoon and Mandalay), the 1,600 km Great Sumatra fault, and the 1,000 km Dead Sea fault. Of the 11 faults classified as 'superhighways', 9 are in Asia and 2 in North America, with 7 located near areas of very dense population. Based on the population distribution within $50 \mathrm{~km}$ of each fault superhighway, obtained from the United Nations database for the Year 2005 (Gridded Population of the World 2007), we find that more than 60 million people today have increased seismic hazards due to such faults. The main aim of this work was to identify those sections of faults where additional studies should be targeted for better understanding of earthquake hazard for these regions. Figure 1.4 shows the world map, with the locations of the superhighways marked, and the world population density. 


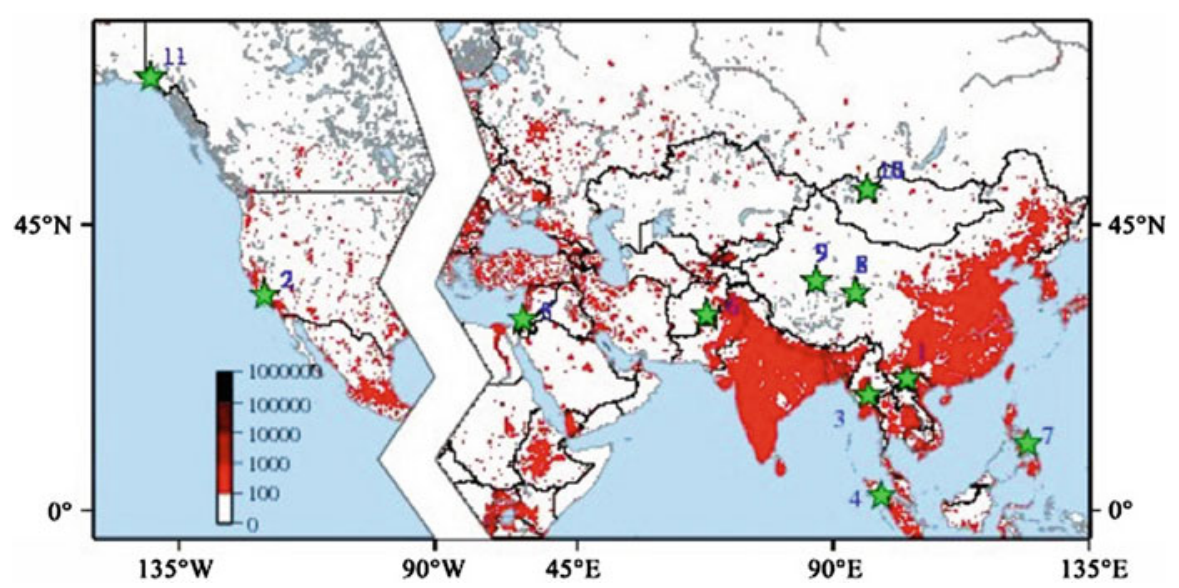

Fig. 1.4 Location of earthquake superhighways worldwide, shown as green stars, numbered as in Table 1.3. The world population (Gridded Population of the World 2007), in inhabitants per $30^{\prime} \times 30^{\prime}$, is coloured as per the key. The zigzag band has no superhighways in it

\subsubsection{The Red River Fault, Vietnam/China}

Since we consider this to be the most dangerous fault in the world (Robinson et al. 2010), as well as one less well studied compare to some other faults, particularly the San Andreas fault, it is discussed here in detail, in order to encourage more detailed studies there. The Red River fault runs for about $1,000 \mathrm{~km}$, through one of the most densely populated regions of the world, from the south-eastern part of Tibet through Yunnan and North Vietnam to the South China Sea. Controversy exists regarding total geological offsets, timing of initiation and depth of the Red River fault. Many authors propose that it was a long-lasting plate boundary (between Indochina and South China 'blocks') initiated $~ 35 \mathrm{Ma}$ ago, accommodating between 500 and 1,050 km of left-lateral offset, and extending down into the mantle. Many others propose that it is only a crustal scale fault, 29-22 Myold. Although mylonites along the metamorphic complexes show ubiquitous left-lateral shear fabrics, geodetic data confirm that recent motion has been right-lateral. Seismic sections across the Red River delta in the Gulf of Tonkin clearly suggest that at least offshore of Vietnam the fault is no longer active.

Although the Red River fault system is highly complex, Robinson et al. (2010) were able to identify three sections of it as having potential for supershear rupture (Fig. 1.5). In Vietnam, the Red River fault branches into numerous strands as it runs through the thick sediments of the Red River delta near Hanoi. Although there is no known record of recent major earthquakes on the main Red River fault in Vietnam (Utsu 2002), two sub-parallel strands of this fault near Hanoi appear remarkably straight, hence we identify two $250 \mathrm{~km}$ sections here as being superhighways. The consequences of a long supershear rupture in this area would be catastrophic. A second, $280 \mathrm{~km}$ long, segment is identified in the Chuxiong Basin section of the 


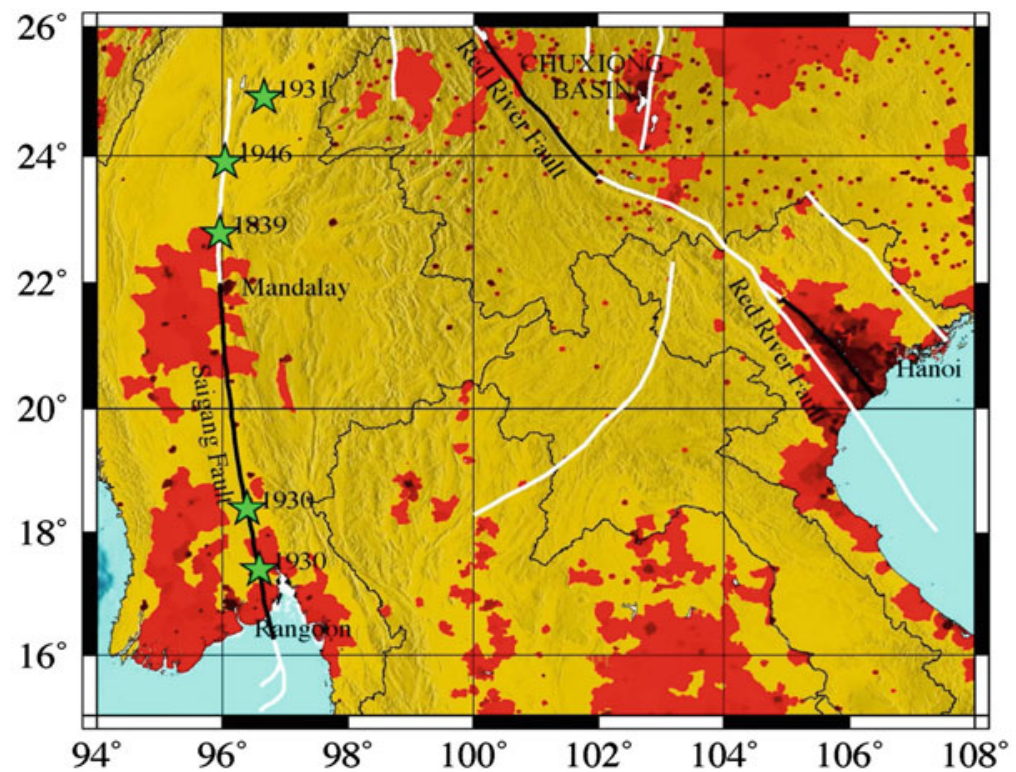

Fig. 1.5 Map of southeastern China, Vietnam and Myanmar showing the $700 \mathrm{~km}$ superhighway of the $1,000 \mathrm{~km}$ long Sagaing fault, Myanmar, and the 280 and $250 \mathrm{~km}$ superhighways of the $800 \mathrm{~km}$ Red River (Honghe) fault. Known faults (Yeats et al. 1997) are shown as white lines, with superhighways shown in black. The world population (Gridded Population of the World) (in inhabitants per $30^{\prime} \times 30^{\prime}$,) is shown, according to the colour key shown in Fig. 1.4, with populations less than 100 people per $30^{\prime} \times 30^{\prime}$ shown as transparent, overlain on a digital elevation map of the region. Locations of known large earthquakes on these faults (Table 1.3) are marked

fault, where it appears to be straight and simple. This area has a long history of documented significant earthquakes on nearby faults (Yeats et al. 1997; Fig. 8.12 of Yeats 2012).

\subsubsection{The Sagaing Fault, Burma}

The second-most dangerous superhighway in Table 1.3 is the San Andreas fault in California but since it has been very heavily discussed in the literature we do not discuss it here. Instead, we discuss the third-most dangerous superhighway. This $1,100 \mathrm{~km}$ long right-lateral strike-slip fault in Myanmar (Burma) forms the presentday eastern plate boundary of India (Fig. 1.5). Estimates of long-term geological offsets along the fault range from 100 to $150 \mathrm{~km}$ to $450 \mathrm{~km}$, motion along the Sagaing Fault probably initiating $22 \mathrm{Ma}$. The Sagaing fault is very continuous between Mandalay and Rangoon, with the central $700 \mathrm{~km}$ from $\left(17\right.$ to $\left.23^{\circ} \mathrm{N}\right)$ being "remarkably linear" (Vigny et al. 2003). It is the longest, continuous linear strikeslip fault identified globally. North of $23^{\circ} \mathrm{N}$, the fault begins to curve slightly but it 
is still possible that supershear rupture could proceed for a considerable distance. We have identified about $700 \mathrm{~km}$ of this fault as having the potential for sustained supershear rupture (Fig. 1.5). There were large earthquakes on the fault in 1931, 1946, 1839, 1929, and two in 1930 (Yeats et al. 1997). With the cities of Rangoon (Yangon) (population exceeding five million) and Mandalay (population approaching one million) at, respectively, the southern and northern ends of this straight portion, supershear earthquakes propagating either northwards or southwards could focus energy on these cities. In addition, the highly populated off-fault regions would have increased vulnerability due to the passing Mach fronts, thereby exacerbating the hazard.

\subsection{Discussion}

Tables 1.1 and 1.2 show that it is only in the last 2 years that we have found the first example of two under-water earthquakes reaching supershear speeds, showing that this is even rarer for marine earthquakes than ones on continents. Very recently, a deep earthquake at $\sim 650 \mathrm{~km}$ depth has been inferred to have had supershear speed (Zhan et al. 2014).

Sometimes earthquakes in very different parts of the world in very different tectonic regimes have remarkable similarities. Das (2007) has compared the 2001 Tibet earthquake and the 1906 California earthquake, the repeat of which would be a far greater disaster, certainly in financial terms, than the 2004 Sumatra-Andaman earthquake and tsunami! They are both vertical strike-slip faults, have similar Mw, fault length and width, and hence similar average slip and average stress drop. The right-lateral 1906 earthquake rupture started south of San Francisco, and propagated bilaterally, both to the northwest and to the southeast. Geodetic measurements showed that the largest displacements were on the segment to the north of San Francisco, which is in agreement with results obtained by inversion of the very few available seismograms. It has recently been suggested that this northern segment may have reached supershear rupture speeds (Song et al. 2008). The fact that the high fault displacement region is where the fault is very straight, would provide additional support to this, if the 1906 and the 2001 earthquakes behaved similarly. Unfortunately, due to heavy rains and rapid rebuilding following the 1906 earthquake, no information is available on whether or not off-fault cracks appeared in this region. The cold desert climate of Tibet had preserved the off-fault open cracks from the 2001 earthquake, un-eroded during the winter months, till the scientists visited in the following spring. Similar considerations deserve to be made for other great strike-slip faults around the world, for example, along the Himalayan-Alpine seismic belt, New Zealand, Venezuela, and others, some of which are discussed next. 
Table 1.1 Recent large strike-slip earthquakes without supershear rupture speed

\begin{tabular}{l|l|l|l|l|l}
\hline Date & Location & Mw & $\begin{array}{l}\text { Fault length } \\
(\mathrm{km})\end{array}$ & $\begin{array}{l}\text { On land or } \\
\text { underwater }\end{array}$ & References \\
\hline 1989 & $\begin{array}{l}\text { Macquarie } \\
\text { Ridge }\end{array}$ & 8.0 & 200 & Underwater & Das (1992, 1993)) \\
\hline 1998 & $\begin{array}{l}\text { Antarctic } \\
\text { Ocean }\end{array}$ & 8.1 & $140,60^{\mathrm{a}}$ & $”$ & Henry et al. (2000) \\
\hline 2000 & Wharton Basin & 7.8 & 80 & $”$ & $\begin{array}{l}\text { Robinson } \\
\text { et al. (2001) }\end{array}$ \\
\hline 2004 & Tasman Sea & 8.1 & $160,100^{\mathrm{a}}$ & & Robinson (2011)
\end{tabular}

${ }^{a}$ Two sub-events

Table 1.2 Strike-slip earthquakes known to have reached supershear rupture speeds

\begin{tabular}{|c|c|c|c|c|c|c|}
\hline Year & Mw & Location & $\begin{array}{l}\text { Supershear } \\
\text { segment } \\
\text { length }(\mathrm{km})\end{array}$ & $\begin{array}{l}\text { Type of data } \\
\text { used to study the } \\
\text { quake }\end{array}$ & $\begin{array}{l}\text { Land } \\
\text { or sea }\end{array}$ & Reference \\
\hline 1979 & 6.5 & $\begin{array}{l}\text { Imperial } \\
\text { Valley, } \\
\text { California }\end{array}$ & 35 & $\begin{array}{l}\text { Strong ground } \\
\text { motion }\end{array}$ & Land & $\begin{array}{l}\text { Archuleta (1984), } \\
\text { Spudich and } \\
\text { Cranswick (1984) }\end{array}$ \\
\hline 1999 & 7.6 & $\begin{array}{l}\text { Izmit, } \\
\text { Turkey }\end{array}$ & 45 & $"$ & $"$ & Bouchon et al. (2002) \\
\hline 1999 & 7.2 & $\begin{array}{l}\text { Duzce, } \\
\text { Turkey }\end{array}$ & 40 & $"$ & $"$ & Bouchon et al. (2001) \\
\hline 2001 & 7.8 & $\begin{array}{l}\text { Kunlun, } \\
\text { Tibet }\end{array}$ & $>400$ & Teleseismic & $"$ & $\begin{array}{l}\text { Robinson } \\
\text { et al. }(2006 a, b)\end{array}$ \\
\hline 2002 & 7.9 & $\begin{array}{l}\text { Denali, } \\
\text { Alaska }\end{array}$ & 340 & $"$ & $"$ & $\begin{array}{l}\text { Walker and Shearer } \\
(2009)\end{array}$ \\
\hline 2012 & 8.6 & N. Sumatra & $200,400,400$ & $"$ & Sea & Wang et al. (2012) \\
\hline 2013 & 7.5 & $\begin{array}{l}\text { Craig, } \\
\text { Alaska }\end{array}$ & 100 & $"$ & $"$ & Yue et al. (2013) \\
\hline
\end{tabular}

\subsection{Future Necessary Investigations}

There are several other faults with shorter straight segments, which may or may not be long enough to reach supershear speeds. Although we do not identify them as fault superhighways, they merit mention. Of these, the $1,400 \mathrm{~km}$ long North Anatolian fault in Turkey is the most particularly note-worthy, since supershear (though not near-compressional wave speed) rupture has actually been inferred to have occurred on it (Bouchon et al. 2001). The fault is characterized by periods of quiescence (of about 75-150 years) followed by a rapid succession of earthquakes, the most famous of these is the "unzipping" of the fault starting in 1939. For the most part the surface expression of the fault is complex, with many segments and en-echelon faults. It seems that large earthquakes (e.g., 1939, 1943, 1944) are able to rupture multiple segments of these faults but it is unlikely that in jumping from one segment to another, they will be able to sustain rupture velocities in excess of 
the shear wave velocity. The longest "straight, continuous" portion of the North Anatolian Fault lies in the rupture area of the 1939 Erzincan earthquake, to the west of its epicenter, just prior to a sharp bend of the fault trace to the south (Yeats et al. 1997). This portion of fault is approximately $80 \mathrm{~km}$ long. Additionally, this branch which continues in the direction of Ankara (the Sungurlu fault zone) appears to be very straight. However, the Sungurlu fault zone is characterized by very low seismicity and is difficult to map due to its segmentation. Thus it is unlikely that supershear rupture speeds could be maintained on this fault for a significant distance. Since the North Anatolian fault runs close to Ankara and Istanbul, it is a candidate for further very detailed in-depth studies.

Another noteworthy fault is the Wairarapa fault in New Zealand, which is reported to have the largest measured coseismic strike-slip offset worldwide during the 1855 earthquake, with an average offset of $\sim 16 \mathrm{~m}$ (Rodgers and Little 2006), but this high displacement is estimated over only $16 \mathrm{~km}$ of its length. Although a $\sim 120 \mathrm{~km}$ long fault scarp was produced in the 1855 earthquake, the Wairarapa fault is complex for much of its length as a series of splay faults branch off it. One straight, continuous, portion of the fault is seen in the Southern Wairarapa valley, but this is only $\sim 40 \mathrm{~km}$ long. Thus it is less likely that this fault could sustain supershear rupture over a considerable distance.

It is interesting to note that since the mid-1970s, when very accurate magnitudes of earthquakes became available, no strike-slip earthquake on land appears to have Mw >7.9 (two earthquakes in Mongolia in 1905 are supposed to have been $>8$, but the magnitudes of such old earthquakes are not reliably known), even some with rupture lengths $>400 \mathrm{~km}$. Yet they can produce surprisingly large damage. Perhaps this could be explained by the multiple shock waves, carrying large ground velocities and accelerations, generated by supershear ruptures. A good example is the 1812 Caracas, Venezuela earthquake, described by John Milne (see Milne and Lee 1939), which devastated the city with more than 10,000 killed in $1 \mathrm{~min}$. The earthquake is believed to be of magnitude about 7.5, and to have occurred on the Bocono fault, which is $\sim 125 \mathrm{~km}$ away (Perez et al. 1997), but there is no known local geological feature, such as a sedimentary basin, to amplify the motion. So one could suggest either that the fault propagated further towards Caracas than previously believed, or reached supershear rupture speeds, or both.

\subsection{Conclusions}

Table 1.3 is ordered by the number of people expected to be affected by a fault superhighway, and the list would look very different if it was listed in financial terms. In addition, faults in less populated areas could then become much more important. The 2011 Christchurch, New Zealand earthquake with a Mw of only 6.1 led to the second largest insurance claim in history (Financial Times, London, March 28, 2012). Even though no supershear rupture was involved in this, it shows that financial losses depend on very different circumstances than simply the number 
Table 1.3 Earthquake fault superhighways

\begin{tabular}{|c|c|c|c|c|c|}
\hline & $\begin{array}{l}\text { Fault system } \\
\text { and location }\end{array}$ & $\begin{array}{l}\text { Total } \\
\text { length } \\
(\mathrm{km})\end{array}$ & $\begin{array}{l}\text { Segment } \\
\text { lengths }{ }^{\mathrm{a}} \\
(\mathrm{km})\end{array}$ & $\begin{array}{l}\text { Affected } \\
\text { population } \\
\text { (millions) }^{\mathrm{b}}\end{array}$ & $\begin{array}{l}\text { Size and dates of past } \\
\text { earthquakes }{ }^{c}\end{array}$ \\
\hline 1 & $\begin{array}{l}\text { Red River, } \\
\text { Vietnam/China }\end{array}$ & 1,000 & $\begin{array}{l}280 \\
230,290\end{array}$ & 25.7 & 7.7 (1733), 8.0 (1833) \\
\hline 2 & $\begin{array}{l}\text { San Andreas, } \\
\text { California } \\
\end{array}$ & 1,050 & 160,230 & 13.1 & 7.9 (1857), 7.9 (1906) \\
\hline 3 & Sagaing, Burma & 1,000 & 700 & 9.1 & $\begin{array}{l}\text { N.D. (1839), } 7.3 \text { (1930), } 7.3 \\
\text { (1930), } 7.6(1931), 7.5 \text { (1936), } \\
7.4 \text { (1946), }\end{array}$ \\
\hline 4 & Great Sumatra & 1,600 & $\begin{array}{l}100, \\
160,220, \\
200\end{array}$ & 6.7 & $\begin{array}{l}7.7(1892), 7.6(1909), 7.5 \\
(1933), 7.4(1943), 7.6(1943)\end{array}$ \\
\hline 5 & $\begin{array}{l}\text { Dead Sea, Jor- } \\
\text { dan/Israel }\end{array}$ & 1,000 & 100,125 & 5.2 & $\begin{array}{l}\text { N.D. (1068), N.D. (1170), } \\
\text { N.D. (1202) }\end{array}$ \\
\hline 6 & $\begin{array}{l}\text { Chaman/Herat, } \\
\text { Pakistan/ } \\
\text { Afghanistan }\end{array}$ & 1,100 & $\begin{array}{l}170 \\
320,210\end{array}$ & 2.5 & N.D. (1892) \\
\hline 7 & $\begin{array}{l}\text { Luzon, } \\
\text { Philippines }\end{array}$ & 1,600 & 130 & 2.1 & $7.8(1990)$ \\
\hline 8 & Kunlun, Tibet & 1,600 & $\begin{array}{l}270, \\
130,180, \\
100\end{array}$ & 0.15 & 7.5 (1937), 7.8 (2001) \\
\hline 9 & $\begin{array}{l}\text { Altyn Tagh, } \\
\text { Tibet }\end{array}$ & 1,200 & $\begin{array}{l}100 \\
100,150\end{array}$ & 0.062 & $7.6(1932)$ \\
\hline 10 & $\begin{array}{l}\text { Bulnay, } \\
\text { Mongolia }\end{array}$ & 300 & 100,200 & 0.020 & $7.8,8.2(1905)$ \\
\hline 11 & Denali, Alaska & 1,400 & 130 & Negligible & $7.8(2002)$ \\
\hline
\end{tabular}

${ }^{a}$ Lengths of straight segments, identified as superhighways, listed from south to north

${ }^{\mathrm{b}}$ Current population, in millions, within $50 \mathrm{~km}$ of the superhighways, this being the region expected to be most damaged by earthquakes propagating along the superhighways

${ }^{\mathrm{c}}$ Magnitude of old earthquakes are surface wave magnitude or moment-magnitude, as available; N.D. if unknown

of people affected. Another interesting example is the 2002 Denali, Alaska fault, which intersects the Trans-Alaska pipeline. Due to extreme care in the original construction (Pers. Comm., Lloyd Cluff), it was not damaged, but the environmental catastrophe for an oil spill in the pristine national park would have had indirect financial consequences, the most important being the possible prevention of it being ever allowed to re-open again. In many places of low population density, Governments may consider placing power plants (nuclear or otherwise), and such installations need to be built keeping in mind the possibility of supershear rupture on nearby faults. Clearly, many other major strike-slip faults worldwide, not classed as a superhighway yet, deserve much closer inspection with very detailed studies to fully assess their potential to reach supershear rupture speeds. 
Acknowledgements I would like to thank two distinguished colleagues, Raul Madariaga and Michel Bouchon, for reading the manuscript and providing many useful comments, which improved and clarified it.

Open Access This chapter is distributed under the terms of the Creative Commons Attribution Noncommercial License, which permits any noncommercial use, distribution, and reproduction in any medium, provided the original author(s) and source are credited.

\section{References}

Aki K, Richards P (1989) Quantitative seismology: theory and methods. WH Freeman and Company, San Francisco

Aki K, Richards P (2002) Quantitative seismology: theory and methods. University Science, Sausalito

Antolik M, Abercrombie RE, Ekström G (2004) The 14 November 2001 Kokoxili (Kunlunshan), Tibet, earthquake: rupture transfer through a large extensional step-over. Bull Seismol Soc Am 94:1173-1194

Andrews DJ (1976) Rupture velocity of plane strain shear cracks. J Geophys Res 81:5679-5687

Archuleta R (1984) Faulting model for the 1979 Imperial Valley earthquake. J Geophys Res 89:4559-4585

Benioff H (1952) Mechanism and strain characteristics of the White Wolf fault as indicated by the aftershock sequence, Earthquakes in Kern County, California during 1952. Bull Calif Div Mines Geology 171:199-202

Ben-Menahem A, Toksöz MN (1962) Source mechanism from spectra of long-period seismic surface waves 1. The Mongolian earthquake of December 4, 1957. J Geophys Res 67:1943-1955

Ben-Menahem A, Toksöz MN (1963a) Source mechanism from spectrums of long-period surface waves: 2. The Kamchatka earthquake of November 4, 1952. J Geophys Res 68:5207-5222

Ben-Menahem A, Toksöz MN (1963b) Source mechanism from spectrums of long-period seismic surface waves. Bull Seismol Soc Am 53:905-919

Bernard P, Baumont D (2005) Shear Mach wave characterization for kinematic fault rupture models with constant supershear rupture velocity. Geophys J Int 162:431-447

Bhat HS, Dmowska R, King GCP, Klinger Y, Rice JR (2007) Off-fault damage patterns due to supershear ruptures with application to the $2001 \mathrm{Mw} 8.1$ Kokoxili (Kunlun) Tibet earthquake. J Geophys Res 112:B06301

Bizzari A, Das S (2012) Mechanics of 3-D shear cracks between Rayleigh and shaer wave speeds. Earth Planet Sci Lett 357-358:397-404

Bouchon M, Toksöz MN, Karabulut H, Bouin MP, Dietrich M, Aktar M, Edie M (2002) Space and time evolution of rupture and faulting during the 199 Izmit (Turkey) earthquake. Bull Seismol Soc Am 92:256-266

Bouchon M, Vallée M (2003) Observation of long supershear rupture during the magnitude 8.1 Kunlunshan earthquake. Science 301:824-826

Bouchon $M$ et al (2010) Faulting characteristics of supershear earthquakes. Tectonophysics 493:244-253

Bouchon M, Karabulut H (2008) The aftershock signature of supershear earthquakes. Science 320:1323-1325

Bouchon M, Bouin MP, Karabulut H, Toksöz MN, Dietrich M, Rosakis AJ (2001) How fast is rupture during an earthquake? New insights from the 1999 Turkey earthquakes. Geophys Res Lett 28:2723-2726 
Bouchon M, Toksoz MN, Karabulut H, Bouin MP, Dietrich M, Aktar M, Edie M (2000) Seismic imaging of the Izmit rupture inferred from the near-fault recordings. Geophys Res Lett 27:3013-3016

Broberg KB (1989) The near-tip field at high crack velocities. Int J Fract 39:1-13

Broberg KB (1994) Intersonic bilateral slip. Geophys J Int 119:706-714

Broberg KB (1999) Cracks and fracture. Academic, New York

Brune JN (1961) Radiation pattern of Rayleigh waves from the Southeast Alaska earthquake of July 10, 1958. Publ Dom Observ 24:1

Brune JN (1962) Correction of initial phase measurements for the Southeast Alaska earthquake of July 10, 1958, and for certain nuclear explosions. J Geophys Res 67:3463

Burridge R (1973) Admissible speeds for plane-strain self-similar shear crack with friction but lacking cohesion. Geophys J Roy Astron Soc 35:439-455

Burridge R, Conn G, Freund LB (1979) The stability of a rapid Mode II shear crack with finite cohesive traction. J Geophys Res 84:2210-2222

Cruz-Atienza VM, Olsen KB (2010) Supershear Mach-waves expose the fault breakdown slip. Tectonophysics 493:285-296

Das S (2007) The need to study speed. Science 317:889-890

Das S (1992) Reactivation of an oceanic fracture by the Macquarie Ridge earthquake of 1989. Nature 357:150-153

Das S (1993) The Macquarie Ridge earthquake of 1989. Geophys J Int 115:778-798

Das S (1976) A numerical study of rupture propagation and earthquake source mechanism DSc thesis, Massachusetts Institute of Technology, Cambridge

Das S, Aki K (1977) A numerical study of two-dimensional rupture propagation. Geophys J Roy Astron Soc 50:643-668

Das S, Kostrov BV (1994) Diversity of solutions of the problem of earthquake faulting inversion: application to SH waves for the great 1989 Macquarie Ridge earthquake. Phys Earth Planet Int 85:293-318

Das S, Kostrov BV (1990) Inversion for slip rate history and distribution on fault with stabilizing constraints - the 1986 Andreanof Islands earthquake. J Geophys Res 95:6899-6913

Das S, Suhadolc P (1996) On the inverse problem for earthquake rupture. The Haskell-type source model. J Geophys Res 101:5725-5738

Das S, Suhadolc P, Kostrov BV (1996) Realistic inversions to obtain gross properties of the earthquake faulting process. Tectonophysics 261:165-177. Special issue entitled Seismic Source Parameters: from Microearthquakes to Large Events, ed. C. Trifu

Dunham EM (2007) Conditions governing the occurrence of supershear ruptures under slipweakening friction. J Geophys Res 112:B07302

Dunham EM, Archuleta RJ (2004) Evidence for a supershear transient during the 2002 Denali fault earthquake. Bull Seismol Soc Am 94:S256-S268

Dunham EM, Bhat HS (2008) Attenuation of radiated ground motion and stresses from threedimensional supershear ruptures. J Geophys Res 113:B08319

Ellsworth WL, Celebi M, Evans JR, Jensen EG, Kayen R, Metz MC, Nyman DJ, Roddick JW, Spudich P, Stephens CD (2004) Nearfield ground motion of the 2002 Denali Fault, Alaska, earthquake recorded at Pump Station 10. Earthq Spectra 20:597-615

Frankel A (2004) Rupture process of the M7.9 Denali fault, Alaska, earthquake: subevents, directivity, and scaling of high-frequency ground motion. Bull Seismol Soc Am 94:S234-S255

Gridded Population of the World, version 3 (GPWv3) (2007) Center for International Earth Science Information Network (CIESIN), Columbia University; and Centro Internacional de Agricultura Tropical (CIAT). 2005, Palisades. Available at http://sedac.ciesin.columbia.edu/ gpw

Hamano Y (1974) Dependence of rupture time history on the heterogeneous distribution of stress and strength on the fault, (abstract). Transact Am Geophys Union 55:352 
Hartzell SH, Heaton TH (1983) Inversion of strong ground motion and teleseismic waveform data for the fault rupture history of the 1979 Imperial Valley, California, earthquake. Bull Seismol Soc Am 73:1553-1583

Hartzell SH, Stewart GS, Mendoza C (1991) Comparison of $\mathrm{L}_{1}$ and $\mathrm{L}_{2}$ norms in a teleseismic waveform inversion for the slip history of the Loma Prieta, California, earthquake. Bull Seismol Soc Am 81:1518-1539

Ida Y (1972) Cohesive force across the tip of a longitudinal-shear crack and Griffith's specific surface energy. J Geophys Res 77:3796-3805

Henry C, Das S (2002) The Mw 8.2 February 17, 1996 Biak, Indonesia earthquake: rupture history, aftershocks and fault plane properties. J Geophys Res 107:2312

Henry C, Das S, Woodhouse JH (2000) The great March 25, 1998 Antarctic Plate earthquake: moment tensor and rupture history. J Geophys Res 105:16097-16119

Kostrov BV (1975) Mechanics of the tectonic earthquake focus (in Russian). Nauka, Moscow

Kostrov BV (1966) Unsteady propagation of longitudinal shear cracks. J Appl Math Mech 30:1241-1248

Kostrov BV, Das S (1988) Principles of earthquake source mechanics. Cambridge University Press, New York

Lin A, Fu B, Guo J, Zeng Q, Dang G, He W, Zhao Y (2002) Co-seismic strike-slip and rupture length produced by the 2001 Ms 8.1 Central Kunlun earthquake. Science 296:2015-2016

Liu C, Bizzari A, Das S (2014) Progression of spontaneous in-plane shear faults from sub-Rayleigh up to compressional wave rupture speeds. J Geophys Res Solid Earth 119 (11):8331-8345

Lasserre C, Peltzer G, Cramp F, Klinger Y, Van der Woerd J, Tapponnier P (2005) Coseismic deformation of the $2001 \mathrm{Mw}=7.8$ Kokoxili earthquake in Tibet, measured by synthetic aperture radar interferometry. J Geophys Res 110:B12408

Madariaga R (1983) High-frequency radiation from dynamic earthquake fault models. Ann Geophys 1:17-23

Madariaga R (1977) High-frequency radiation from crack (stress drop) models of earthquake faulting. Geophys J Roy Astron Soc 51:625-651

Milne J, Lee AW (1939) Earthquakes and other earth movements. K Paul, Trench, Trubner and Co., London

Olson AH, Apsel RJ (1982) Finite faults and inverse theory with applications to the 1979 Imperial Valley earthquake. Bull Seismol Soc Am 72:1969-2001

Ozacar AA, Beck SL (2004) The 2002 Denali fault and 2001 Kunlun fault earthquakes: complex rupture processes of two large strike-slip events. Bull Seismol Soc Am 94:S278-S292

Parker RL (1994) Geophysical inverse theory. Princeton University Press, Princeton

Passelègue FX, Schubnel A, Nielsen S, Bhat HS, Madariaga R (2013) From sub-Rayleigh to supershear ruptures during stick-slip experiments on crustal rock. Science 340 (6137):1208-1211

Perez OJ, Sanz C, Lagos G (1997) Microseismicity, tectonics and seismic potential in southern Caribbean and northern Venezuela. J Seismol 1:15-28

Press F, Ben-Menahem A, Toksöz MN (1961) Experimental determination of earthquake fault length and rupture velocity. J Geophys Res 66:3471-3485

Press WH, Flannery BP, Teukolsky SA, Vetterling WT (1986) Numerical recipes: the art of scientific computing. Cambridge University Press, New York

Robinson DP, Das S, Searle MP (2010) Earthquake fault superhighways. Tectonophysics 493:236-243

Robinson DP (2011) A rare great earthquake on an oceanic fossil fracture zone. Geophys J Int 186:1121-1134

Robinson DP, Das S, Watts AB (2006a) Earthquake rupture stalled by subducting fracture zone. Science 312:1203-1205

Robinson DP, Brough C, Das S (2006b) The Mw 7.8 Kunlunshan earthquake: extreme rupture speed variability and effect of fault geometry. J Geophys Res 111:B08303 
Robinson DP, Henry C, Das S, Woodhouse JH (2001) Simultaneous rupture along two conjugate planes of the Wharton Basin earthquake. Science 292:1145-1148

Rodgers DW, Little TA (2006) World's largest coseismic strike-slip offset: the 1855 rupture of the Wairarapa Fault, New Zealand, and implications for displacement/length scaling of continental earth-quakes. J Geophys Res 111:B12408

Rosakis AJ, Samudrala O, Coker D (1999) Cracks faster than the shear wave speed. Science 284:1337-1340

Sarao A, Das S, Suhadolc P (1998) A comprehensive study of the effect of non-uniform station distribution on the inversion for seismic moment release history and distribution for a Haskelltype rupture model. J Seismol 2:1-25

Spudich P, Cranswick E (1984) Direct observation of rupture propagation during the 1979 Imperial Valley earthquake using a short baseline accelerometer array. Bull Seismol Soc Am 74:2083-2114

Song SG, Beroza GC, Segall P (2008) A unified source model for the 1906 San Francisco earthquake. Bull Seismol Soc Am 98:823-831

Tarantola A (1987) Inverse problem theory. Methods for data fitting and model parameter estimation. Elsevier, New York

Utsu T (2002) A list of deadly earthquakes in the world (1500-2000). In: Lee WHK, Kanamori H, Jennings PC, Kisslinger C (eds) International handbook of earthquake and engineering seismology part A. Academic, New York, p 691

Vallée M, Landès M, Shapiro NM, Klinger Y (2008) The 14 November 2001 Kokoxili (Tibet) earthquake: High-frequency seismic radiation originating from the transitions between sub-Rayleigh and supershear rupture velocity regimes"'. J Geophys Res 113:B07305

Vigny C, Socquet A, Rangin Chamot-Rooke N, Pubellier M, Bouin M-N, Bertrand G, Becker M (2003) Present-day crustal deformation around Sagaing fault, Myanmar. J Geophys Res 108:2533

Walker KT, Shearer PM (2009) Illuminating the near-sonic rupture velocities of the intracontinental Kokoxili Mw 7.8 and Denali fault Mw 7.9 strike-slip earthquakes with global P wave back projection imaging. J Geophys Res 114:B02304

Wang D, Mori J, Uchide T (2012) Supershear rupture on multiple faults for the Mw 8.6 off Northern Sumatra, Indonesia earthquake. Geophys Res Lett 39:L21307

Wu FT, Thomson KC, Kuenzler H (1972) Stick-slip propagation velocity and seismic source mechanism. Bull Seismol Soc Am 62:1621-1628

Xia K, Rosakis AJ, Kanamori H (2004) Laboratory earthquakes: the sub-Rayleigh-to-supershear transition. Science 303:1859-1861

Xia K, Rosakis AJ, Kanamori H, Rice JR (2005) Laboratory earthquakes along inhomogeneous faults: directionality and supershear. Science 308:681-684

Xu X, Chen W, Ma W, Yu G, Chen G (2002) Surface rupture of the Kunlunshan earthquake (Ms 8.1), northern Tibet plateau, China. Seismol Res Lett 73:884-892

Yeats RS, Sieh K, Allen CR (1997) The geology of earthquakes. Oxford University Press, New York

Yeats R (2012) Active faults of the world. Cambridge University Press, New York

Yue H, Lay T, Freymuller JT, Ding K, Rivera L, Ruppert NA, Koper KD (2013) Supershear rupture of the 5 January 2013 Craig, Alaska (Mw 7.5) earthquake. J Geophys Res 118:5903-5919

Zhan Z, Helmberger DV, Kanamori H, Shearer PM (2014) Supershear rupture in a Mw 6.7 aftershock of the 2013 Sea of Okhotsk earthquake. Science 345:204-207 